\title{
Art Appreciation as a Learned Competence: A Museum-based Qualitative Study of Adult Art Specialist and Art Non-Specialist Visitors
}

RAJKA BRAČUn SOVA ${ }^{1}$

$\approx$ Since Bourdieu, it has been argued that art appreciation requires "knowledge". The focus of this qualitative study was to examine art appreciation as a learned competence by exploring two different groups of museum visitors: art specialists and art non-specialists. The research was conducted at Moderna galerija in Ljubljana. Twenty-three adults were recruited and accompanied during their visit to the museum. Participants were requested to "think out loud", which meant to talk about what they saw, thought, and felt about the artworks. There was a short interview conducted with each participant before entering the museum to gain insight into their art-related and museum-visiting experience. The analysis of the data revealed that some processes of art appreciation were similar within the two groups. Both art specialists and art nonspecialists interact with museum objects physically and intellectually; they see contents and formal qualities as a whole; they respond emotionally to artworks; appreciation includes their personal experience; they search museum interpretation/information for their understanding. Some noticeable differences were found. Art specialists respond to artworks with more understanding and are willing to put more effort into art appreciation, whereas art non-specialists respond with less understanding and put less effort into art appreciation. This paper focuses on the differences between the two groups; reflective and spontaneous appreciation of art, objective and subjective appreciation of art and the effort put into art appreciation. The paper ends with a discussion of the implications of the study for the teaching of art and museum education.

Keywords: art appreciation, adult museum visitors, art specialists, art non-specialists, competence

1 Pedagoginja v kulturi in kustosinja [Educator in culture and curator]; rajkabracun@gmail.com 


\section{Likovna apreciacija kot privzgojena zmožnost: muzejska kvalitativna študija odraslih obiskovalcev - poznavalcev in nepoznavalcev likovne umetnosti}

RAJKa BRAČUN SOVA

$\propto$ Od Bourdieuja je znano, da likovna apreciacija (človekovo doživljanje oziroma razumevanje likovnih umetnin) zahteva »znanje«. Ta kvalitativna študija se osredinja na raziskovanje likovne apreciacije kot privzgojene zmožnosti, in sicer tako, da preučujemo dve različni skupini muzejskih obiskovalcev: poznavalce in nepoznavalce likovne umetnosti. Raziskava je potekala v Moderni galeriji v Ljubljani. Sodelovalo je triindvajset odraslih, pri čemer smo jih spremljali med njihovim obiskom muzeja. Udeležence smo prosili, da "mislijo na glas«, kar pomeni, da govorijo o tem, kar vidijo, razmišljajo in čutijo ob ogledovanju umetnin. Pred obiskom muzeja smo vsakega udeleženca tudi intervjuvali, da bi pridobili vpogled v njihove izkušnje, povezane z likovno umetnostjo in obiskovanjem muzejev. Analiza podatkov je pokazala, da so nekateri procesi doživljanja oziroma razumevanja umetnin pri obeh skupinah podobni. Poznavalci in nepoznavalci vstopajo $\mathrm{v}$ interakcijo $\mathrm{z}$ muzejskimi predmeti na fizični in intelektualni ravni; vsebino in formalne značilnosti doživljajo kot celoto; na umetniška dela se čustveno odzivajo; v svoja doživljanja umetnin vnašajo osebne izkušnje; v procesu razumevanja umetnin iščejo muzejsko interpretacijo oziroma informacije. Odkrili pa smo tudi nekatere opazne razlike. Poznavalci umetniška dela bolj razumejo in so pripravljeni vložiti več v doživljanje umetnin, medtem ko nepoznavalci umetniška dela manj razumejo in $\mathrm{v}$ doživljanje umetnin vložijo manj. $\mathrm{V}$ tem članku se osredinjamo na razlike med obema skupinama: reflektivno in spontano doživljanje oziroma razumevanje umetnosti, nepristransko in pristransko doživljanje oziroma razumevanje umetnosti ter vložek v doživljanje oziroma razumevanje umetnosti. Prispevek se konča s pomenom študije za šolsko poučevanje likovne umetnosti in muzejsko pedagogiko.

Ključne besede: likovna apreciacija, odrasli muzejski obiskovalci, poznavalci likovne umetnosti, nepoznavalci likovne umetnosti, zmožnost 


\section{Introduction}

In Slovenia, research into art appreciation has started to develop. This paper takes as its starting point the fact that "museums are where the great majority of people in the West today encounter art" (McClellan, 2006, p. xiii) and thus presents a study that is conceptually and methodologically museumbased. The term "museums" is used here to refer to art museums (galleries) with most of their collections and exhibitions devoted to visual art objects. The research reported upon is a qualitative study of a group of art specialists and a group of art non-specialist adults responding to artworks in Moderna galerija in Ljubljana. An analytical framework, used for the analysis of interviews, relates to the association between art education and people's ability to appreciate and understand works of art.

This research continues with empirical evidence that showed that school support for learning about art is weak in Slovenia; the art curriculum is centred principally on art-making activities, with an obvious neglect of appreciation (Bračun Sova \& Kemperl, 2012). This is problematic if we realize that people's interest in art is developed in (and beyond) school, as UK- and US-based studies and reports indicate (e.g. Hooper-Greenhill et al., 2001; Hooper-Greenhill \& Moussouri, 2001; Zakaras \& Lowell, 2008).

Current research into art appreciation in Slovenia does not go further than measuring the predominantly pre-determined levels of perception and reception of female and male pupils in school, whereby reproductions of artworks by modernist and contemporary artists, such as Paul Cézanne and Jorge Rodrigues Gerada, are used for observation (Duh, Zupančič, \& Čagran, 2014; Duh \& Korošec, 2014; Duh, 2014). There are also some methodological issues, for example, the absence of coding, categorizing and conceptualization in qualitative data analysis. The empirical literature in this paper, however, includes critical specifics about learning processes in museums as authentic places of art. The research is grounded in a more complex understanding of art appreciation as a learned competence and examines education-related differences in people's ability to appreciate works of art.

\section{Framework for Understanding Art Appreciation as a Learned Competence}

It was Bourdieu who first coined the concept "competence" when discussing the ability to enjoy and understand art. In his study of visitors to museums and art galleries, conducted in the 196os, he determined that the level 
of educational attainment and occupational status had a direct bearing on museum attendance and the quality of museum experience. He argued that the ability to enjoy and understand art is not self-evident, but "cultivated", that is learned: "[...] aesthetic pleasure presupposes learning and, in any particular case, learning by habit and exercise" (Bourdieu \& Darbel, 1969/1991, p. 109).

The approach to art appreciation adopted for this paper is that presented by Olsen (1998, p. 66), who sees it as "not untrained perception, but the outcome of a long process of initiation and practice." Barrett (2007, p. 651) writes that art appreciation is an engaged activity that requires knowledge: "Appreciation is a complex act of cognition that is dependent on relevant knowledge of what is appreciated." Appreciation involves knowledge of various sorts, such as art-historical knowledge, historical knowledge, and other factors (see HooperGreenhill, 1999).

Some authors have researched the processes of seeing, experiencing and understanding art in a museum setting. Research first focused on art specialists (museum professionals with art background and experience: curators, educators and managers) and aimed to develop a model of ideal aesthetic experience (e.g. Csikszentmihalyi \& Robinson, 1990). The comparative approach followed, whereby researchers compared art specialists and art non-specialists (e.g. Lachapelle, 1999). Then the interest in mixed visitors' processes of learning in art museums (e.g. Hooper-Greenhill \& Moussouri, 2001; Hooper-Greenhill et al., 2001) and art non-specialists (e.g. Lachapelle, 2007; Lachapelle et al., 2009) started to grow, whereby the research approach moved from the comparative to the differentiated one. Today, museum visitor studies are being complemented by research into interpretive resources, made by curators, such as labels, guidebooks and tours, as well as architectural modes of communicating art in museums (e.g. Fritsch, 2011).

From these studies, some theories are relevant to our research into art appreciation. To begin with, they all take as their basic premise that artworks in museums are "primary evidence for establishing and furthering knowledge" and that museums provide "opportunities for the appreciation and understanding of heritage" (cf. ICOM, 2013). Museums are thus authentic places for appreciating art, where artworks are "objects of learning" (Tavčar, 2009, p. 78). Art objects have a "deliberately communicative and expressive function," but they can "also be read for their unintended messages" (Hooper-Greenhill, 1991, p. 99).

Csikszentmihalyi and Robinson (1990) identified four dimensions of seeing and experiencing artworks: intellectual, communicative, perceptive and emotional. They see appreciation as an interaction between the viewer, a work 
of art and an artist, and stress that the viewer has to be skilled in appreciation in order to understand the work of art in all its dimensions.

Hooper-Greenhill and her research team, who asked individual adult visitors to Wolverhampton Art Gallery and Nottingham Castle Museum and Art Gallery to share their immediate thoughts about the artworks, determined that the ability to appreciate artworks was correlated to the visitor's personal background. The ability to talk about and understand how space is created in paintings, how colours are used to represent and communicate ideas and feelings and the ability to talk about and understand the subject matter, to mention a few examples of interpretive strategies, were affected by education, socio-economic status and interest in art (Hooper-Greenhill \& Moussouri, 2001; Hooper-Greenhill et al., 2001).

The educational and other contexts of the museum experience are also discussed by Falk and Dierking (2013). The researchers of museums as learning places argue that the understanding and appreciation of art, history, science and other topics in museums is built on the interaction between the visitor's prior knowledge and experience, motivation, interests, attitudes, expectations, and identities ("personal context") and immediate social and physical environments ("sociocultural" and "physical contexts"). Lachapelle et al. (2003) focus on the role of knowledge in art appreciation. They define four kinds of knowledge: mediative, objectified, (re-)constructed and theoretical. Mediating knowledge is subject-centred; it is "the personalized body of knowledge that the viewer brings with him or her to the aesthetic encounter" (p. 85). Objectified knowledge is located in a museum object; "it is the knowledge that the work of art makes concrete and perceptible" (p. 86). Objects thus have explanatory power. The interaction of mediating knowledge and objectified knowledge produces constructed knowledge and is a result of experiential learning. The fourth type of knowledge is theoretical, which means contextual information about the artwork provided by the museum. It is needed in order to foster "not only aesthetic understanding but also aesthetic development" (p. 88). Whitehead (2012, p. 40) calls it "received knowledge" and sees it as an important part of learning in art museums.

In a study conducted at the National Gallery of Canada, Lachapelle (1999) used a cognitive framework to explore expertise-related differences in art viewers' strategies for responding to works of art. Ten adult participants (five art specialists and five art non-specialists) volunteered to share their insights about selected works of art. The research showed that the two groups used essentially the same psychological operations to interpret works of art. Noticeable differences were found in the content of those operations. Expert 
participants made greater use of disciplinary knowledge in formulating their ideas about art objects, while non-expert participants relied, to a far greater extent, on their personal experiences as a source of knowledge to inform their understanding of artworks.

The theories described in this literature review are helpful in providing a framework for understanding the association between education/enculturation and people's ability to appreciate and understand works of art. We have found, however, that none of these studies addresses the problem by combining non-expert and expert participants and non-directed technique of examining their ability to appreciate art. The methodological framework of this study is presented in the next chapter.

\section{Methodology: Moderna galerija as a Site of Naturalistic Inquiry}

I conducted my research at Moderna galerija in Ljubljana, which is a national museum of Slovenian modern art. Data was collected from January to June 2012 at a new permanent display entitled $20^{\text {th }}$ Century: Continuities and Ruptures. The exhibition begins with the topic the Entry of Modernism into Slovenian Art, marked by impressionists, and ends with the ten-day war for Slovenian independence in 1991, when New Collectivism designed, printed and hung a number of posters all over the capital. Between these two points, there is Expressionism, the New Objectivity, the Generation of the Independents, the Avant-Garde of the 1920s, Art of the Partisan Resistance, After Liberation: Socialist Realism and Modernism, a New Approach to Painting in the 1970s, Art Informel, Expressive Figurative Art, Neo-Constructivism, OHO, and in the 1980s: the New Image, Retro-Avant-Garde with Neue Slowenische Kunst (Irwin, Laibach, Sisters Scipio Nasice Theatre, New Collectivism), and the Alternative Culture. In the foyer, the Student Movement 1968-1972 is presented. The main innovations in this exhibition are the presentation of the avant-garde and the second reconstruction of the Trieste Constructivist Space (1927), the art of the Partisan resistance, photography, and an overview of the art system in Slovenia in the $20^{\text {th }}$ century.

The display is arranged broadly chronologically with one integrated quasi non-chronological theme. In a separate leaflet and a guide book, there is an explanation of the display's expository logic, priming visitors to design their own itineraries according to their needs.

A qualitative approach was taken employing a combination of research methods, including in-depth interviews with art specialist and non-specialist 
adult visitors responding to artworks (the "think out loud" technique), pre-visit short interviews about participants' backgrounds, observations and field notes. In order to analyse and interpret data, I used a mixture of ideas from the qualitative methodology theory, particularly the constant comparison method and the triangulation strategy (see Flick, 2009).

Twenty-three adults with different educational backgrounds were recruited and accompanied during their visit to the museum. The most important criteria for selecting participants was education: art specialists were defined as those participants who had professional university training in art and were normally involved in art-related careers, while art non-specialist were defined as participants with education and careers in any discipline except fine arts. I accessed potential interviewees in many ways. I started the recruitment during the two-week observation of museum visitors' behaviour in the gallery; individuals, who agreed to participate, were contacted again for the interview. I found some informants among my acquaintances: adult ex-students of art, older adult students at the Third Age University, and museum professionals. I also relied on contacts given by the interviewees themselves. As Rapley (2004, p. 17) writes, "recruitment routinely happens on an ad-hoc and chance basis."

Twelve art specialists and eleven art non-specialists participated: a student of art history in the upper grade, a student of art history in the final year of study, an unemployed art education teacher, an employed art education teacher, a researcher in the field of art history, a freelance artist with fine arts education, two journalists with art history education, three art museum curators, a teacher of maths, a retired architect, a researcher in the field of urbanism, an accountant soon to be retired, a manager in tourism, a retired sales representative, a retired marketing officer in the pharmaceutical industry, a retired medical nurse, a retired economist, and a retired analytics officer. Six participants were male; seventeen were female. They were between 22 and 81 years old.

Participants were individually requested to "think out loud", which means to talk about what they saw, thought and felt about the chosen artworks and the exhibition as a whole. The researcher's role was limited to prompting participants for further explanation where needed. Their verbal discourse was recorded using a digital recorder. Participants were free to choose the exhibits they wanted to visit, to determine the pace of the visit and time they wanted to spend at each exhibit and in the museum as a whole. Two exhibits were suggested by the researcher (if not previously chosen by the participant), to ensure to get the response of all participants to the same artworks: a figurative painting Peasant Wedding by Tone Kralj (made in 1926) and a non-figurative painting Untitled by Tomo Podgornik (made in 1976). 
There was a short interview conducted with each participant before entering the museum, because the researcher was interested in the participants $\mathbb{}$ interest in art and museum-visiting experiences. Data from introductory interviews were combined with data obtained from interviews in the museum, and the researchers' observations and field notes, gathered at the end of each visit.

\section{Results: Differences in Art Appreciation between Art Specialists and Art Non-Specialists}

Different themes have emerged from the analysis of conversations. Participants talked not only about specific works of art but also about their ideas about art in general and experiences with museums. When looking at art objects in the museum, they responded on two levels. On one level they referred to the artwork: they commented on the visual qualities, the subject-matter, the technique, and other elements. By looking at certain figurative artworks they "travelled in time in space". On another level, they referred to themselves: they made all sorts of personal associations with the artworks, predominantly with the scenes depicted on paintings and presented in sculpture. Both object-related and subject-related responses were at times emotional. Participants were generally interested in the titles of the artworks and the name of the artist. The research indicated that participants would need more contextual information for a better understanding although when certain information is provided (e.g. Avant-Garde room), not all participants will use it.

In the following paragraphs, the differences in art appreciation competences between art specialists and art non-specialists will be presented. The findings are organized and analysed around three key themes. Each theme/category is illustrated with verbatim quotations.

\section{Reflective appreciation, spontaneous appreciation}

The response of art specialists was one of reflective recognition. This is an appreciative awareness of how the artwork is made to be viewed and understood. They responded to different dimensions of artworks and used the knowledge of art concepts and vocabulary when talking about artworks. For example, they not only mentioned colour but explained how colour is used to represent and communicate ideas and feelings. Art specialists not only described what they saw in artworks and looked for messages but also evaluated them. Some art specialists also critically talked about the relationship between the artwork and the museum. 
One of the art specialists described this way of understanding artworks:

Well, if I know the sculptor or painter, and I know what I can expect, then I am somehow predetermined (Int.11).

The appreciation of art non-specialists was one of spontaneous reaction, an intuitive and less-considered consideration of artworks. They do not possess learned strategies to appreciate art such as comparing styles, looking for symbols, and so on. They did observe and talk about the different characteristics of an artwork, but their approach was not so analytical. For example, they were less able to talk about how the visual qualities of artworks are combined to convey the meaning of the artwork. They enjoyed the artworks by making personal associations, and they used everyday language and experience, not related to the art, to describe what they see and feel. An example of Tone Kralj's painting Peasant Wedding (1932) illustrates this:

I think that he [the painter] knew Breughel, knew Northern Renaissance painters, the Peasant Wedding. The figures are so down to earth, so powerful. You can see right away that they are somewhere in the country. Such a joyful ball (Int. 1, art specialist).

I experienced exactly the same kind of wedding for real. When I was young, I saw it in a course book, or an art history book. I saw it, the painting, but now it is appealing to me because I attended exactly the same type of wedding. My brother's wedding, in 1980. In a small farm house that was crowded very much like this house here, the stove, everything was the same, everything but the masks, there were no masks if I remember correctly. The atmosphere was unique, super. Moreover, the musician who played music and games, boosting our emotions. We were so many that today I do not think this would be possible. Such a joy! Oh God, is it possible? This is how we were sitting (he shows: that close). Everything was tasty, delicious. I remember now. It was the same. And there were children next to the stove. That can't be true! It had come back to my memory when I came closer to the painting (Int. 16, art non-specialist).

These results correspond to Lachapelle's (1999) findings of experts using art-related types of information and non-experts using personal types of information when interpreting artworks. 


\section{Objective appreciation, subjective appreciation}

Art non-specialists respond to artworks in a more subjective way. I define subjective appreciation as a personally involved action, whereby emotional affection does not enable the objective appreciation and understanding of an artwork. Some visitors were simply not able to look at some artworks. Here is an example of a 75-year-old visitor, who was not able to appreciate certain artworks made by Božidar Jakac:

Božidar Jakac has some nice pictures too, but some are more, how shall I say, particularly those from the times of the Partisan resistance, representing horrors and the like, which I do not like to look at. Those were terrible times, and I do not like them being pictured and I do not like to see them in a painting (Int. 20).

One of the visitors explained that paintings "are not of the kind one would like to look at, because they trigger negative feelings" (Int. 19). It seems that the non-ability to appreciate and understand paintings is a result of some emotional involvement that predominantly relates to the person who is looking at the artwork, and not the artwork itself.

Another participant in the study, who is an art specialist, while looking at Zoran Mušičs painting We Are Not The Last reported upon an interesting experience of her mother. Her mother is an art non-specialist, but has a great interest in art and has some prominent Slovenian modernist artists in her private art collection at home (she also participated in the research).

I have always liked Mušič. We Are Not the Last is a very, very... of course a terrible motif. We have one of his paintings at home. It pictures something like soil, but you can spot, it is blurred, a skull there. The skull can hardly be seen. One day, I had hung the picture on the wall above the TV, and I asked my mother: "Can you see there a skull like in We Are Not The Last?" She said: "Where?" I showed her where it was in the painting. She said: "I don't see it." I thought I was mistaken. But since that moment I told her about the skull she has refused to have the painting hung on the wall. Even though she ca not see well! She doesn't see at all! But she doesn't want [to look at it], she doesn't want to have it there (Int. 22).

The same visitor explained her way of appreciating art (see below). As an art specialist, she responds to artworks in a more objective way. (She described 
it as 'non-personal.') I define objective appreciation as a neutral action, where the viewer experiences the artwork with a certain degree of personal and emotional distance, which enables him/her objective construction of the meaning of the artwork. While art non-specialists report not being able to enjoy artworks, art specialists are able to enjoy artworks (they are interested in 'what the artist wanted to communicate').

I like to immerse myself into certain [art historical] periods, although I know that bad things happened then. Here [resistance art] it is difficult not to think about what happened. There was war, but I still like to look [at artworks] (Int. 22).

Art specialists' appreciation is not based on personal attitudes, emotions or opinions, but relates to different aspects of an artwork. In this sense, they are able to appreciate artworks with more understanding of its function and meaning. It is the artwork that generates their ideas about the reality and their beliefs about what is good, true, fair, worthy, and so on. Let us see how the participant responded to the art of the Partisan resistance (why she 'likes to look'):

I think, I feel somehow responsible to ... No matter what time the picture depicts, or no matter what kind of past injustice ... that may still be there ... I feel I should take time, because some people have suffered. I think this is important, taking time, because terrible events should not happen again (like the one depicted by Mušič in We are not the last). But they will, for sure. And then I do not know ... As a historian, I have always felt some kind of ... the Second World War has always interested me. I used to research the Holocaust (I used to read about it a lot). Those times are extremely heart-breaking. It breaks my heart hearing people say: "It was horrible, but now we are safe", And then you see that we are not. There was this war in Bosnia, not to mention it, but also the war in Vietnam and there is war elsewhere, in Congo or Soudan. And it makes me sad, and then I think that war will always be, that there is no salvation; through all history it has been like this (Int. 22).

In the same manner, she described her way of appreciating avant-garde art. Despite the idea of "militarism", which she "personally does not like", she still "likes these paintings" and "is interested in this art". She regards art in general as "something, which makes you think, which wakes you and makes the world move" (Int. 22). 


\section{Effort put into art appreciation}

The research has showed that art specialists are willing to put more effort into art appreciation, whereas art non-specialists are not willing to do so. What does this mean?

Firstly, it seems that art specialists are open to different artistic styles and try to enjoy and also understand new kinds of art. They do have pre-formed interests ("What I like, when I get enchanted by an exhibition room, I can sit there for half an hour or so, what I do not like, I just pass by" (Int. 14)), but at the same time they seem to be interested in learning "something new":

I could not say that I divide art into historical and contemporary art. But I think I prefer more traditional practices, that is painting, sculpture, graphic illustration, drawing, prints, more than contemporary art practices, for example, video installations. But occasionally I do make an effort to see this art as some sort of counterweight. And to expose myself as a viewer to something new - to something, I am not so familiar with (Int. 8).

Art non-specialists are less willing to accept different kinds of art. When they do not understand, they do not understand. A visitor looking at Matej Sternen's painting Pigeons (Still-life) had difficulties in "seeing" the pigeons and in understanding this impressionist painting as a modernist artwork:

One doesn't want to put effort into this. With so much other beauty, that you can always find in galleries, there is no time, or it is not reasonable or possible for me to figure out what a painting is all about. What sort of impression he [the painter] wanted to achieve. Or: what he wanted to tell me. Or: what he wanted to leave behind him. What? [He reads the label.] Sternen, Pigeons, Still-life. Now I am angry because I cannot see the pigeon (Int. 16).

Another female art non-specialist visitor, aged 69, explained that her ability to learn is in a way limited. She is not so willing to learn about art anew:

I do learn, but I am not ready to learn just anything. I have to be interested in it (Int. 18).

Secondly, the effort put into art appreciation also relates to the use of museum information for visitors' understanding. Although both art specialists 
and art non-specialists showed the need for more contextual information, not all would use them in the same manner or to the same extent. It seems that art specialists would put more effort into reading museum texts and learning about artefacts than art non-specialists would, as the example of the AvantGarde room showed (the room is fully walled with texts, images and artworks):

During my last visit to this gallery, I took time and read this (Int. 22, art specialist).

You need to have time to study all this. If one is interested, one will read it. [...] Myself, I don't think that I would take time and read all this. That I would come to this room only to read this, I do not think so. Not at my age! (Int. 18, art non-specialist).

(The Trieste Constructivist Space, 1927)

Visitor: How could this [artwork] merit so much effort and such a place [in the gallery]. (laugh)

Researcher: Do you want to know why...

Visitor: I keep asking myself the same question. I would need somebody to tell me.

Researcher: We have some information here.

Visitor: Oh, I wouldn't make an effort to go through this (int. 16, art non-specialist).

Thirdly, art specialists and art non-specialists also differ in museum participation. Art specialists not only visit art museum collections and exhibitions on a frequent basis but also revisit them, while art non-specialists invest less time and energy into visiting art museums.

\section{Implications for the Teaching of Art and Museum Education}

The results presented above have some implications for the teaching of art and museum education. They are discussed with references to certain literature.

Teachers should know that in order to appreciate historical and contemporary art, one needs understanding. The ability or competence to look with understanding at and respond to artworks is a learned competence. This research was conceptualized by examining two "extreme" groups of participants 
- art specialists and art non-specialists - in order to show education-related differences in people's competence to appreciate works of art. Participants with specific knowledge of art responded to artworks with more understanding and were willing to put more effort into art appreciation, whereas participants with an "ordinary" artistic background responded with less understanding and invested less time and energy into seeing, experiencing and understanding art.

Barrett (2007, p. 639) writes that "art appreciation is generally assumed and often explicitly claimed to be the desired outcome of art education". Art education is therefore considered to be education for art appreciation, most notably for visiting art museum collections and exhibitions in adulthood. Teachers should be aware that museum-visiting in adulthood is not compulsory, but a "free-choice" activity (Falk \& Dierking, 200o), similar to watching TV, reading literature, going to the theatre, and other forms of cultural engagement. This study involved adult participants who visit museums in their free time. The study confirmed that knowledge of art, interest in art and museum-visiting experiences shape the potential art museum visitor: his or her immediate understanding of artworks, openness to experience new art, actual use of museum information and general attitude towards museums.

This study also has some specific implications for museum educators. Educators in museums should be aware that not all visitors have the ability to engage in art appreciation processes equally. The "problem" of differences between reflective and objective appreciation on one side and spontaneous and subjective appreciation on the other side, revealed by this study, should be addressed in museums by interpretation (in its various forms), as already suggested by previous scholars (e.g. Lachapelle, 1999). Our results suggest that the general public would not put much effort into using it. However, this question remains open because the research in Moderna galerija has its limits as far as museum interpretation is concerned.

\section{Conclusion}

Key findings of the study into adult museum visitors and their art appreciation correspond to some previous museum-based research (e.g. Lachapelle, 1999; Hooper-Greenhill \& Moussouri, 2001), which indicated that the visitor's ability to appreciate artworks relates to the level of his or her knowledge of art. The analysis of the research data has led us to conclude that there are similarities, but also dissimilarities between the two groups of adults participating in this study.

Art specialists respond to artworks reflectively and objectively, which leads to better understanding of an artwork, whereas art non-specialists 
respond spontaneously and subjectively, which leads to a poorer understanding of an artwork. They also differ in the amount of effort put into appreciating and understanding different art, seeing and experiencing new art, making use of contextual information, and the time and energy put into art museum-visiting.

The aim of this qualitative museum-based study was not to present experiences of art-specialists as being the sole legitimate ones. After all, art non-specialists greatly outnumber people with expert artistic knowledge, and it should be of interest to museums to understand their ways of seeing, experiencing and understanding works of art. "Appreciation is a complex phenomenon deserving of continued research about if, when, and how learners achieve appreciation in their present lives, what and who they appreciate, and if it lasts through their lifetimes" (Barrett, 2007, p. 652). This study provides art educators and museum educators with some insights into the natural processes of art appreciation. Further research could be focused more on the educational potential of art museums' interpretive resources and the ways art museum professionals can facilitate the learning processes of museum visitors.

\section{References}

Barrett, T. (2007). Teaching Toward Appreciation in the Visual Arts. In L. Bresler (Ed.), International Handbook of Research in Arts Education (vol. 2, pp. 639-654). Dordrecht: Springer.

Bourdieu, P., \& Darbel, A. [1969] (1991). The Love of Art: European Art Museums and their Public. Cambridge: Polity Press.

Bračun Sova, R., \& Kemperl, M. (2012). The Curricular Reform of the Art Education in Primary School in Slovenia in Terms of Certain Components of European Competence of Cultural Awareness and Expression. CEPS Journal, 2(2), 71-91.

Duh, M., \& Korošec, A. (2014). The Development of Art Appreciation Abilities of Pupils in Primary School. The New Educational Review, 36(2), 42-54.

Duh, M., Zupančič, T., \& Čagran, B. (2014). Development of Art Appreciation in 11-14 year-old Students. The International Journal of Art \& Design Education, 33(2), 208-222.

Duh, M. (2014). Razvijanje likovne apreciacije s srednješolci. Pedagoška obzorja, 29(1), 60-75. Falk, J. H., \& Dierking, L. D. (200o). Learning from Museums: Visitor Experiences and the Making of Meaning. Walnut Creek, Lanham, New York, Oxford: AltaMira Press.

Falk, J. H., \& Dierking, L. D. (2013). The Museum Experience Revisited. Walnut Creek: Left Coast Press.

Flick, U. (2009). An Introduction to Qualitative Research. Los Angeles, London, New Delhi, Singapore: Sage Publications.

Fritsch, J. (Ed.) (2011). Museum Gallery Interpretation and Material Culture. London, New York: Routledge. 
Hooper-Greenhill, E. (1991). Museum and Gallery Education. Leicester: Leicester University Press. Hooper-Greenhill, E. (1999). Learning in Art Museums: Strategies of Interpretation. In E. HooperGreenhill (Ed.), The Educational Role of the Museum (pp. 44-52). London, New York: Routledge. Hooper-Greenhill, E., \& Moussouri, T. (2001). Making Meaning in Art Museums 2: Visitors" Interpretive Strategies at Nottingham Castle Museum and Art Gallery. Leicester: Research Centre for Museums and Galleries (RCMG), University of Leicester.

Hooper-Greenhill, E., Moussouri, T., Hawthorne, E., \& Riley, R. (2001). Making Meaning in Art Museums 1: Visitors" Interpretive Strategies at Wolverhampton Art Gallery. Leicester: Research Centre for Museums and Galleries (RCMG), University of Leicester.

ICOM. (2013). ICOM Code of of Ethics for Museums. Paris: International Council of Museums. Lachapelle, R. (1999). Comparing the Aesthetic Responses of Expert and Non-Expert Viewers.

Canadian Review of Art Education, 26(1), 6-21.

Lachapelle, R. (2007). Non-Expert Adults" Art-Viewing Experiences: Conjugating Substance with Struggle. In P. Villeneuve (Ed.), Art Museum Education in the 21st Century (pp. 123-128). Reston (VA): National Art Education Association.

Lachapelle, R., Douesnard, M., \& Keenlyside, E. (2009). Investigating Assumptions about the Relationship between Viewing Duration and Better Art Appreciation. Studies in Art Education, 5o(3), 245-256.

Lachapelle, R., Murray, D., \& Neim, S. (2003). Aesthetic Understanding as Informed Experience: The Role of Knowledge in our Art Viewing Experiences. Journal of Aesthetic Education, 37(3), 78-98.

McClellan, A. (Ed.) (2006). Art and its Publics. Museum Studies at the Millenium. Malden, Oxford, Carlton: Blackwell Publishing.

Olsen, S. H. (1998). Appreciation. In M. Kelly (Ed.), Encyclopedia of Aesthetics (pp. 66-68). Oxford:

Oxford University Press.

Rapley, T. (2004). Interviews. In C. Seale, G. Gobo, J. F. Gubrium, \& D. Silverman (Eds.), Qualitative Research Practice (pp. 15-33). London, Thousand Oaks, New Delhi: Sage Publications.

Tavčar, L. (2009). Homo spectator. Uvod v muzejsko pedagogiko. Ljubljana: Pedagoški inštitut. Whitehead, C. (2012). Interpreting Art in Museums and Galleries. London, New York: Routledge. Zakaras, L., \& Lowell. F. J. (2008). Cultivating Demand for the Arts: Arts Learning, Arts Engagement, and State Arts Policy. Pittsburgh: RAND Corporation. 


\section{Biographical note}

RAJKA BRAČUn Sova received a B.A. in art history (University of Ljubljana, Faculty of Arts), an M.A. in museum and gallery management (City University London), and a PhD in teacher education - art teaching (University of Ljubljana, Faculty of Education). She is an independent educator in culture. She teaches art history at the Third Age University and researches museum education (particularly education in art museums) and visual art didactics. She co-developed a study programme in museum education at University of Ljubljana, Faculty of Education. As an external collaborator of the faculty she is involved in the carrying out of some study subjects in the fields of museum education, history of art and aesthetic education. 